\title{
QUANTIFYING SPATIAL VARIABILITY OF SOIL AND LEAF NITROGEN, PHOSPHOROUS AND POTASSIUM OF BASAL STEM ROT INFECTED OIL PALMS USING GEOSPATIAL INFORMATION SYSTEM
}

\author{
NUR SHUHADA TAJUDIN*; MOHAMED HANAFI MUSA**; IDRIS ABU SEMAN ${ }^{\star}$ and CHE NURUL AINI \\ CHE AMRI*
}

\begin{abstract}
Basal stem rot disease (BSR) is known to be responsible for yield losses in oil palm plantations in Southeast Asia. A balance nutrient in soil and leaf is known to improve the plant health and disease resistance. In order to observe how nitrogen $(N)$, potassium $(P)$ and phosphorus $(K)$ content in soil and leaf affect the BSR occurrence, a field study was conducted in infected blocks of oil palms at two different ages. Nutrients variability ( $N, P$ and $K)$ were obtained, analysed and mapped using classical statistics and geospatial method. Correlated to BSR disease, total $N$ and available $P$ in soil were found to be high in both blocks. However, exchangeable K exhibited low level. Total $N$ and available $P$ in soil of Blocks 1 and 2, and $N$ and $P$ in leaves of Block 1 showed a significant association with the disease $(p<0.01)$. The generated variability map and significant correlations revealed that imbalanced nutrient content occurred in the study area. This would be one of the causes that lead to the disease outbreak.
\end{abstract}

\section{Keywords: oil palm, basal stem rot, nutrient, geostatistic, geospatial.}

Date received: 9 April 2019; Sent for revision: 6 May 2019; Accepted: 25 September 2019; Available online: 27 August 2020.

\section{INTRODUCTION}

Oil palm (Elaeis guineensis Jacq.) was originated from West Africa and introduced firstly to Brazil and other tropical countries in the $15^{\text {th }}$ century. Currently, Malaysia accounts for $39 \%$ of the world oil palm production and $44 \%$ of world exports (USDA,

* Department of Plant Science, Kulliyyah of Science, International Islamic University Malaysia,

25200 Kuantan, Pahang, Malaysia.

E-mail: nurshuhada@iium.edu.my

** Department of Land Management, Faculty of Agriculture, Universiti Putra Malaysia, 43400 UPM, Serdang, Selangor, Malaysia.

‡ Malaysian Palm Oil Board, 6 Persiaran Institusi, Bandar Baru Bangi, 43000 Kajang, Selangor, Malaysia.
2012). However, a basidiomycete fungus, Ganoderma which causes decay at the stem base devastates thousands of hectares of oil palms in South-east Asia especially in Malaysia and Indonesia. A number of factors, such as age of the oil palm, types of soil, and nutrients status were reported to influence the basal stem rot (BSR) disease development. Macroand micro-nutrient were observed to be associated with the disease, where nutrient imbalance in soil and plant likely plays an important role in the disease occurrence. However, the effect appears to be related to the nature of the soil and its chemical properties (Ariffin et al., 2000). Studies have found that increase in nitrogen $(\mathrm{N})$ fertiliser had increased the BSR incidence in nursery condition (Singh, 1990; Tayeb et al., 2003). In contrast, fertiliser trials conducted on a recent marine alluvium of Bernam 
series with a heavy clay soil showed that potassium (K) fertiliser had significantly reduced the incidence, whilst nitrogen $(\mathrm{N})$ and phosphorous (P) only showed a slight increase in the disease incidence (Singh, 1990). Nutrients are important to both crop and microorganisms, and they are also important in controlling disease occurrence (Agrios, 2005). It affects disease tolerance through alteration of the plant's physiology, integrity of the cell walls, membrane leakage, and the chemical composition of the plants (Graham and Webb, 1991). It is reported that the content of essential nutrients, such as $\mathrm{N}$, $\mathrm{P}, \mathrm{K}$, calcium $(\mathrm{Ca})$ and magnesium $(\mathrm{Mg})$ effects disease incidence and severity (Huber and Graham, 1999). Excessive application of $\mathrm{N}$ on plant infected with Puccinia graminis has shown an increase in the disease severity (Howard et al., 1994), while increase on the application of $\mathrm{K}$ on plants infected by the same disease had reduced the disease severity. Other studies reported that adequate application of $\mathrm{Ca}$ had increased the protection of peanuts pods from Rhizoctonia and Pythium infection (Huber, 1980). For soil borne pathogens such as Ganoderma, the most common symptoms are the root infection and decay. It reduces the ability of the root to provide the plant with water and nutrients (Huber and Graham, 1999). This consequence is more severe when the levels of nutrients are marginal especially for nutrients which are immobile.

Most of the studies on BSR disease were conducted at nursery stage focusing on molecular and genetic works. Limited information could be found on nutrient variability in oil palm and in relation with nutrients that affect the disease distribution in the field scale. Plant disease management practices can be improved by putting epidemiological information in the same format as other farm information using a geographic information system (GIS). A GIS is a computer system capable of assembling, storing, manipulating and displaying data referenced by geographic coordinates (Nelson et al., 1999). It has been used widely in accommodating the biosecurity assessment of plant health (Lindgren, 2012). GIS technique has been used to monitor $40 \%$ losses of cotton production infested by Rotylenchulus reniformis in Brazil. Amber et al. (2005) used several spatial analytical techniques and GIS to observe relationships between corn rootworm metapopulation dynamics, soil texture and elevation. Information derived from the spatial analyses demonstrated that GIS information can be used for spatially explicit models to predict future pest populations and formulate more well-informed pest management decisions. Therefore, this study focused at an area which had been identified as having a large number of oil palms infected with BSR disease. In order to manage and monitor a large area, one of better solutions in helping the industry is by applying the GIS technologies. Therefore, this study was carried out with the following objectives: (1) to obtain the spatial variability of N, P and K of soil and leaves of oil palm infected with BSR disease using GIS analysis at two different ages of oil palm, and (2) to observe the correlation of BSR disease incidence with nutrients in soil and leaves at two different ages of oil palm.

\section{MATERIALS AND METHODS}

\section{Study Area}

The study was carried out in Seberang Perak $\left(4^{\circ} 06^{\prime} 41.50^{\prime \prime} \mathrm{N}, 100^{\circ} 53^{\prime} 05.71^{\prime \prime} \mathrm{E}\right)$, Peninsular Malaysia in 2012. Two blocks of oil palm representing the matured oil palms (Block 1) and young oil palms (Block 2) were selected (Figure 1) with an area of 10.7 and 14.1 ha, respectively. Block 1 is the first generation of oil palm planted in 1994 (18 years old), while Block 2 is the second generation planted in 2006 (6 years old). Previously, Block 1 was planted with coconut palms before it was transformed into an oil palm plantation, while Block 2 was under Felcra replanting programme after the first generation of oil palms were cut down. Within four years of record, the BSR disease distribution increased each year starting from 2009 to 2012 in both young and mature oil palm blocks. In mature and young oil palm blocks, $10.33 \%$ and $0.56 \%$ of oil palms, respectively, were infected with BSR disease in 2009. However in 2012, it increased to $50.21 \%$ and $14.84 \%$ for mature and young palm respectively.

\section{BSR Disease Census and Disease Density Map}

Disease identification was done visually on each oil palm of each block based on the conditions of the standing oil palm in October 2012. It was divided into two categories, ' 0 ' for uninfected and ' 1 ' for oil palms that were confirmed infected with BSR disease. The BSR infected oil palm was determined based on the appearance of multiple spear leaves, pale leaf canopy, presence of fruiting bodies at the stem base, and collapse of leaf canopy (Figure 2), while a healthy oil palm was represented by a green leaves with healthy leaves and stem. Ground census was conducted in Blocks 1 and 2 simultaneously. Coordinates of the study area and each oil palm were recorded by using handheld GPS receiver (Garmin GPS 12 XL). To facilitate data integration and spatial analysis, all data were projected into the same geographic coordinate system using WGS 84/ UTM zone $47 \mathrm{~N}$. By using projected coordinate of each standing oil palm, the census maps of Blocks 1 and 2 were generated. Then, disease density map was performed using geostatistical tools of ArcGis 9.3 software based on the features of each standing palm. This technique shows a precise view of oil 


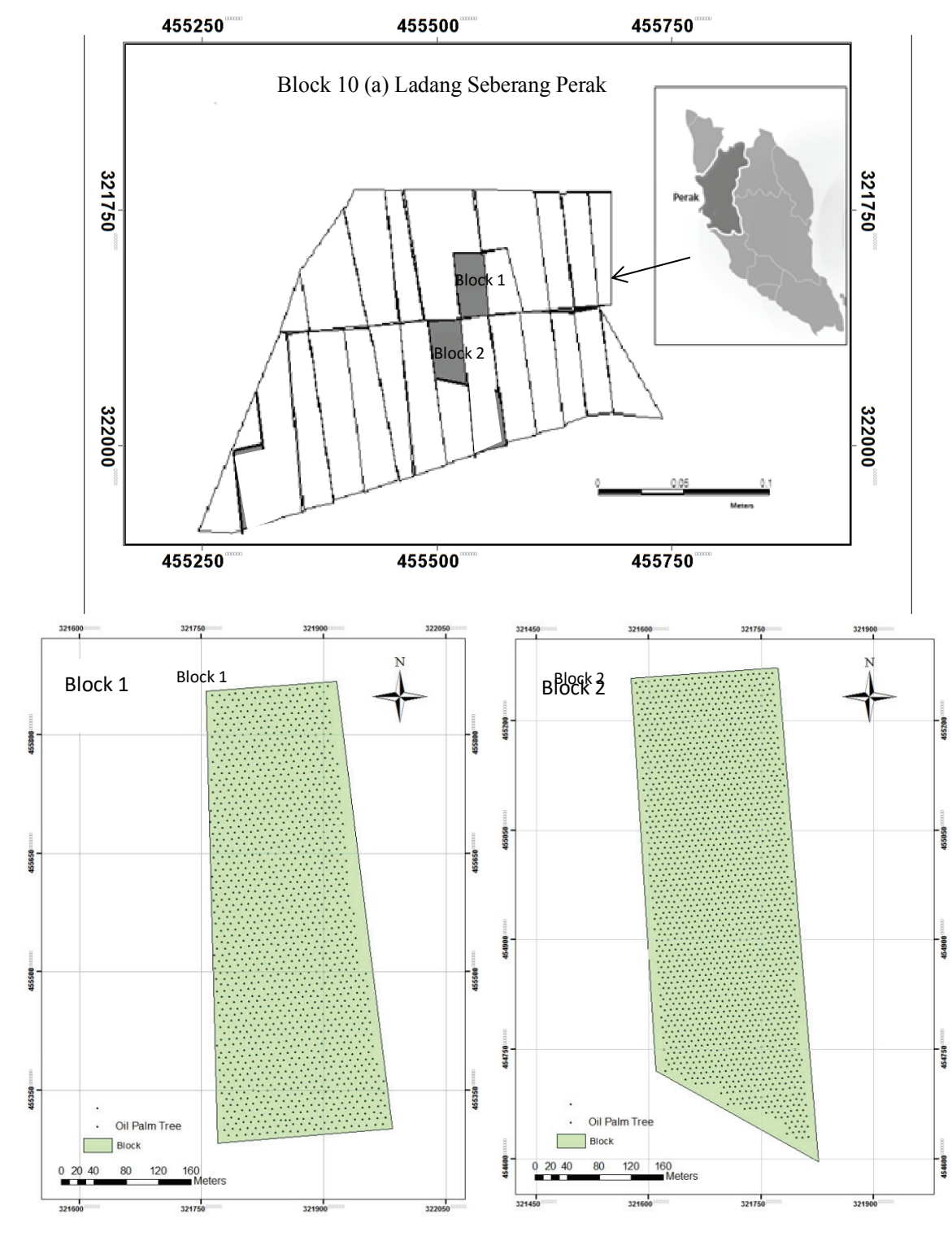

Figure 1. Study area of Blocks 1 and 2 in Felcra Seberang Perak, Perak, Malaysia.

palm features by factoring in impact of area. For the disease density estimation, the disease categories were done based on values as suggested by Singh et al. (1990), which described that any 30\% of the area affected by Ganoderma incidence will reduce the fresh fruit bunches (FFB) yield by $26 \%$ of FFB yield (Table 1).

TABLE 1. BASAL STEM ROT (BSR) ZONE BASED ON LOSSES OF OIL PALM PER HECTARE

\begin{tabular}{ccc}
\hline $\begin{array}{c}\text { Losses of oil palm } \\
\text { by BSR disease } \\
\text { per hectare (\%) }\end{array}$ & $\begin{array}{c}\text { Number of oil } \\
\text { palm infected }\end{array}$ & $\begin{array}{c}\text { Category } \\
\text { suggested }\end{array}$ \\
\hline$<15$ & $<20$ & Very low \\
30 & $21-40$ & Low \\
45 & $41-60$ & Medium \\
60 & $61-80$ & High \\
$>75$ & $>81$ & Very high \\
\hline
\end{tabular}

\section{Soil Sampling}

Soil samples were obtained systematically by grid sampling technique consisting of 60 georeference points each in Blocks 1 and 2 (Figure 3). Sampling points were spaced approximately $36 \mathrm{~m}$ in $\mathrm{X}$ direction and $36 \mathrm{~m}$ in $\mathrm{Y}$ direction. Three composite samples (palm circle, between two palms and frond heap) were obtained at 0 to $20 \mathrm{~cm}$ depth from each sampling point. Soil total $\mathrm{N}$ was determined by using Kjedahl digestion method (Bremmer and Muvaney, 1982). The available P (av. P) was determined by the Bray II method (Bray and Kurtz, 1945), and exchangeable K (ex. K) was determined by neutral ammonium acetate extraction methods (Scholleneberger and Simon, 1945). All elements were measured using auto analyser (AA) (Perkin Elmer 900T, USA). Evaluation of the N, P and $\mathrm{K}$, status in soil were based on threshold value suggested by Goh and Chew (1997). 


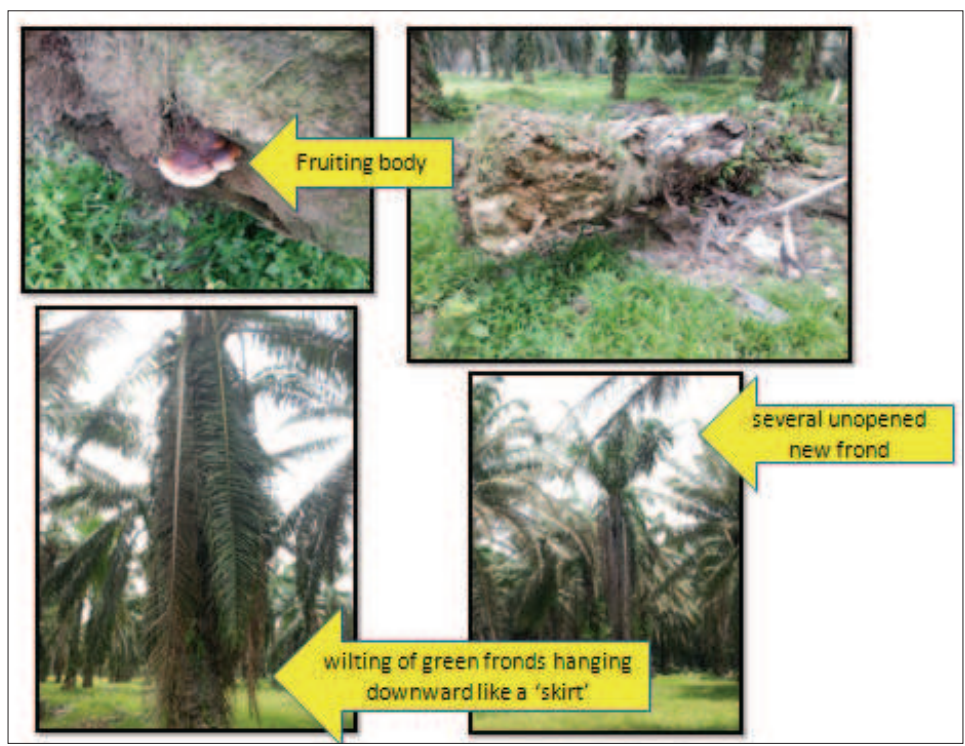

Figure 2. Oil palm with basal stem rot (BSR) disease symptom.

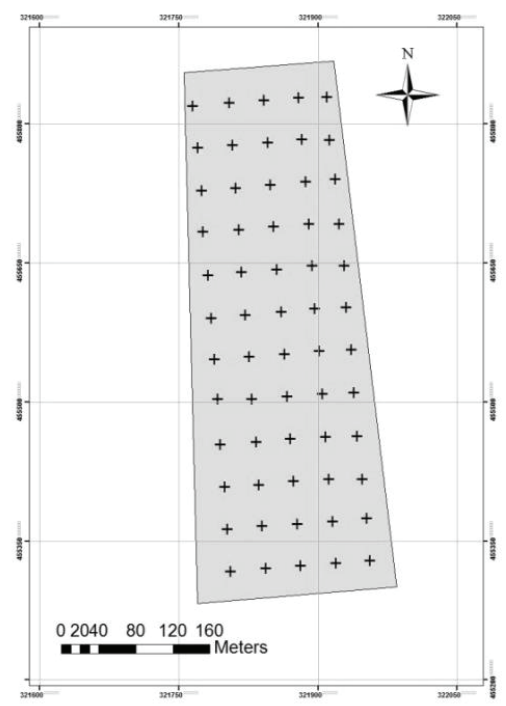

(a)

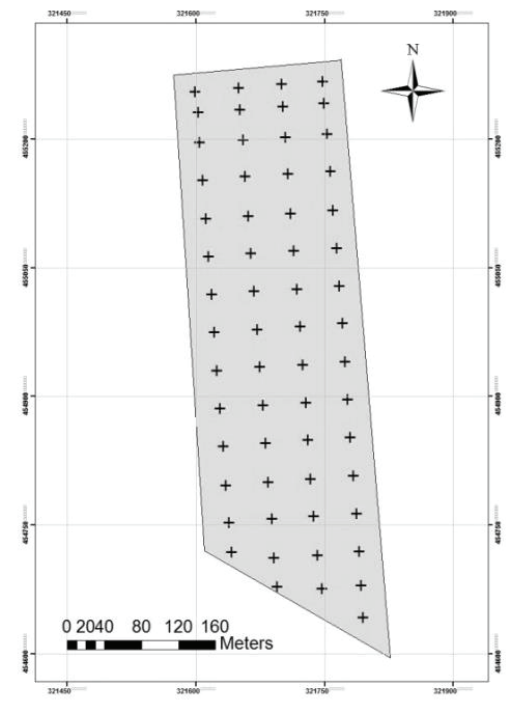

(b)

Figure 3. Sampling point of Blocks 1(a) and 2(b).

\section{Leaf Samples}

A total of 60 samples of oil palm leaves were collected at the same sites as the soil samples (Figure 3). Fronds number $17^{\text {th }}$ and $9^{\text {th }}$ of matured and young palms, respectively were collected for analysis. The leaves were bulked together in a clean polyethylene bag and brought to the laboratory for analysis. Middle $20 \mathrm{~cm}$ of the leaves were cut and retained for laboratory test of total $\mathrm{N}, \mathrm{P}$ and $\mathrm{K}$. Leaflets were oven dried at $60^{\circ} \mathrm{C}-70^{\circ} \mathrm{C}$ for two days. Dried samples were ground into fine forms. A total weight of $0.25 \mathrm{~g}$ foliar tissue sample was digested with $\mathrm{H}_{2} \mathrm{SO}_{4}$ filtered and measured by using AA. Leaf nutrient properties obtained in this study were evaluated based on threshold values as suggested by Von Uexkull and Fairhust (1991).

\section{Geostatistical Analysis}

Variograms measure and model the spatial dependence of variables such as nutrients by using a semi-variance (Burgess and Webster, 1980). They were calculated for each nutrient as follows (Isaaks and Srivasta, 1989; Webster and Oliver, 1992):

$$
\gamma(h)=0.5 \mathrm{n}(\mathrm{h}) \sum_{i=1}^{n(h)}[\mathrm{z} i-\mathrm{z} i+h] 2
$$

where $n(h)$ is the number of pairs of data locations a vector $h$ apart, $h$ is the separation distance between location, $\mathrm{zi}$ or $\mathrm{zi}+\mathrm{h}$ are the measured values for regionalised variable at location at any separation distance $h$. 
A semi-variogram, models the continuity of the spatial variable to a spatial structure. It is described by several parameters such as sill, nugget and range. The nugget is the positive intercept of the variogram with the ordinate and represents unexplained spatially dependent variation or purely random variance. Transitive variogram reaches a sill value at which they level out, at a distance known as the range of spatial dependence. Common transitive models are the spherical, exponential, Gaussian, hole effect or wave and pure nugget. Several trials of semi-variogram function were then applied to choose the best fit model with the existing data. This was done to provide a description of how the data were correlated with distance. This was also done to observe how the data was spatially dependence within each other. A large distance will lead to higher semi-variance and vice versa (Dorsel, 1997). From the best semi-variogram, the model, and value of nugget, sill, range and spatial dependence were calculated. Semi-variogram of each nutrient was computed using $\mathrm{GS}^{+}$version 7 (Gamma Software Design, Plainwell, MI). Spatial dependence was defined as in Table 2 following Cambardella et al. (1994).

TABLE 2. DEFINITION OF SPATIAL DEPENDENCE

\begin{tabular}{ll}
\hline Value & Spatial dependence \\
\hline$<0.25$ & Strong spatial dependence \\
$0.25-0.75$ & Moderate spatial dependence \\
$>0.75$ & Weak spatial dependence \\
\hline
\end{tabular}

\section{Correlations of N, P and K with Disease Incidence}

Blocks 1 and 2 were divided into 60 sub-unit cells, spaced $36 \mathrm{~m}$ in the $\mathrm{X}$ direction and $36 \mathrm{~m}$ in $\mathrm{Y}$ direction. Each sub-unit cell consists of 36 to 40 oil palms. The percentage of oil palms infected with BSR disease was calculated based on the number of diseased oil palms per number of all oil palms in each sub-unit cell. Soil and leaf (60 samples each) that were collected at the centre part of the sub-unit cells, which representing the sub-unit nutrient content were correlated with the percentage of BSR infected in each sub-unit cell. Two tailed Pearson correlation analysis by SAS 9.2 software was used to measure the strength and direction of the linear relationships between the two variables.

\section{RESULTS AND DISCUSSION}

\section{BSR Disease Census}

Distribution of BSR disease varied from very low to very high risk of infected areas (Figure 4a). In 2012, Block 1 was dominated by moderate to a very high category of area infected with BSR disease. About $18 \%$ (1.9 ha) of the area in this block was represented by a very high infected category and another $26 \%$ (2.73 ha) was under high risk category. However, $94 \%$ of the area in Block 2 (Figure 5a) was dominated by very low and low categories of BSR infected areas. Only $0.55 \%$ of the area in Block 2 was classified into a very high incidence of BSR disease.

One of the causes for the spread of BSR in Block 1 was through root contact with the sources of Ganoderma inoculum. This could be from the leftover inoculum of the alternate host plants or through root contact with infected oil palms (Chung, 2011). The area was previously planted with coconut and has not been properly sanitised. This increased the potential of the BSR disease to spread rapidly.

\section{Descriptive Statistic}

Soil $\mathrm{pH}$ in the study area was categorised into acidic type of soil and ranged from 3.05 to 5.85 . The oil palm has the ability to tolerate acidic type of soil and capable of growing well under broad scale of $\mathrm{pH}$, ranging from 4.00 to 5.50 (Goh and Chew, 1995). From Table 3, the content of av. P and ex. $\mathrm{K}$ in soil showed high to very high variation, while total $\mathrm{N}$ showed only an average variation in both blocks based on the coefficient of variation (CV) (Pimentel Gomes and Garcia, 2002). The high variability of av. P and ex. K had been reported as a common occurrence in soils due to intrinsic variation, land use and management. However, lower $\mathrm{CV}$ value in total $\mathrm{N}$ was most likely due to the characteristics of this element, which was mobile in soil (Brady, 1990; Havlin et al., 1999).

TABLE 3. DESCRIPTIVE STATISTIC OF LEAF AND SOIL IN BLOCKS 1 AND 2

\begin{tabular}{|c|c|c|c|c|c|c|c|c|c|c|c|c|}
\hline & \multirow{2}{*}{ Elements } & \multicolumn{2}{|c|}{ Mean } & \multicolumn{2}{|c|}{ Std. dev. } & \multicolumn{2}{|c|}{ Min } & \multicolumn{2}{|c|}{ Max } & \multicolumn{2}{|c|}{$\mathrm{CV} \%$} & \multirow{2}{*}{ Optimum value } \\
\hline & & B1 & B2 & B1 & B2 & B1 & B2 & B1 & B2 & B1 & B2 & \\
\hline \multirow{3}{*}{ Soil } & Total N (\%) & 0.29 & 0.29 & 0.05 & 0.03 & 0.17 & 0.24 & 0.40 & 0.43 & 16.84 & 11.48 & $\begin{array}{c}\text { (Goh and Chew, 1997) } \\
0.15\end{array}$ \\
\hline & Av. P (ppm) & 45.81 & 40.73 & 16.94 & 11.29 & 10.34 & 22.85 & 74.04 & 88.10 & 36.97 & 27.72 & 20 \\
\hline & Ex. K $\left(\mathrm{cmol} \mathrm{kg}^{-1}\right)$ & 0.23 & 0.21 & 0.09 & 0.07 & 0.08 & 0.10 & 0.42 & 0.48 & 37.40 & 36.32 & 0.25 \\
\hline \multirow{4}{*}{ Leaf } & & & & & & & & & & & & $\begin{array}{l}\text { (Von Uexkull and } \\
\text { Fairhust, 1991) }\end{array}$ \\
\hline & $\mathrm{N}(\%)$ & 2.98 & 3.36 & 0.40 & 0.33 & 2.03 & 2.65 & 3.75 & 4.25 & 13.42 & 9.82 & $2.40-2.80$ \\
\hline & $\mathrm{P}(\%)$ & 0.20 & 0.30 & 0.03 & 0.06 & 0.11 & 0.22 & 0.35 & 0.55 & 30.00 & 22.58 & $0.15-0.18$ \\
\hline & $\mathrm{K}(\%)$ & 0.50 & 0.65 & 0.22 & 0.10 & 0.19 & 0.24 & 1.08 & 0.89 & 44.00 & 24.61 & $0.90-1.20$ \\
\hline
\end{tabular}



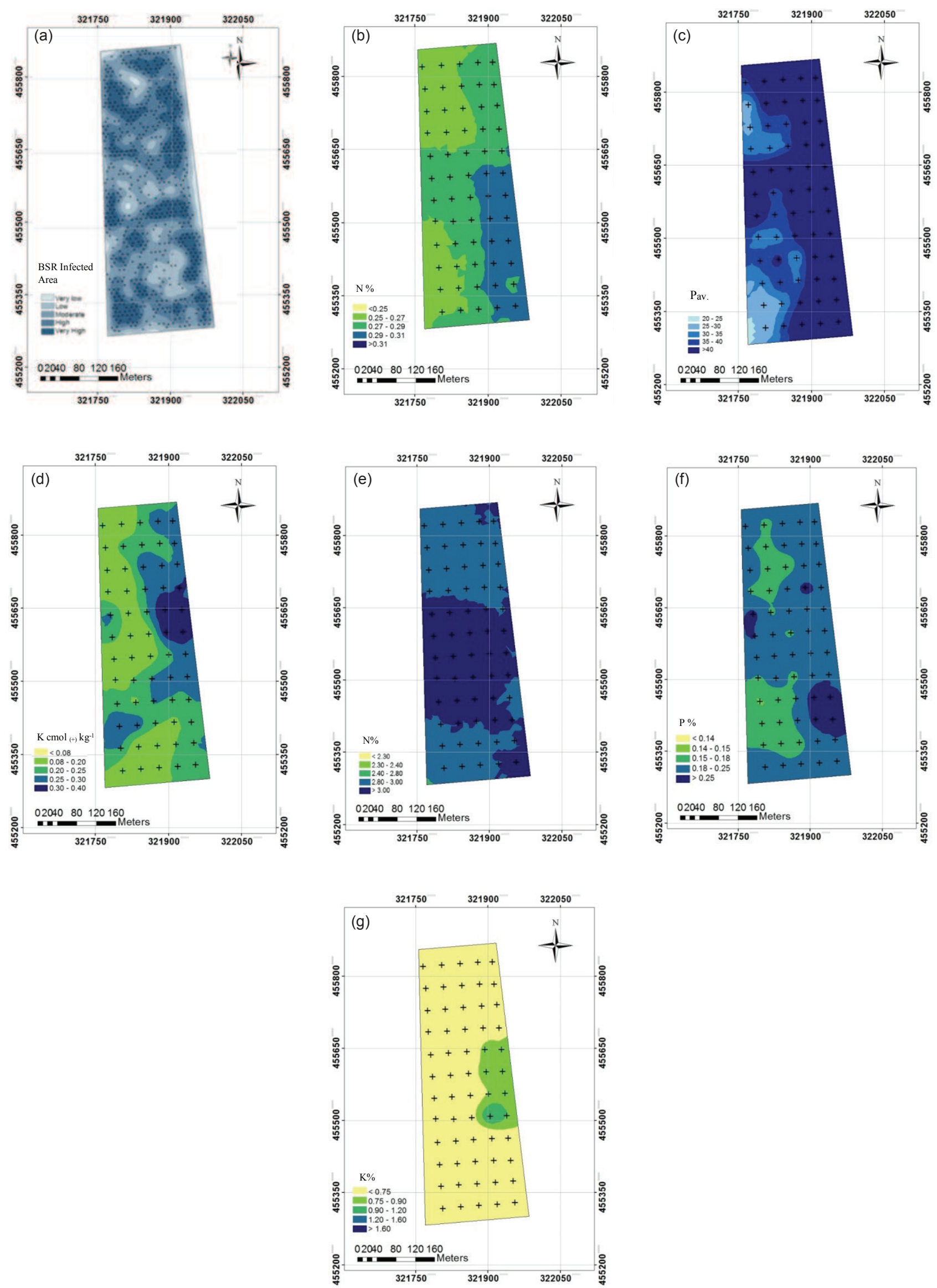

Figure 4. Distribution of basal stem rot (BSR) infected oil palms (a) and spatial variability of nitrogen (N), phosphorus (P) and potassium (K) in soil $(b-d)$ and leaf $(e-g)$ of Block 1. 

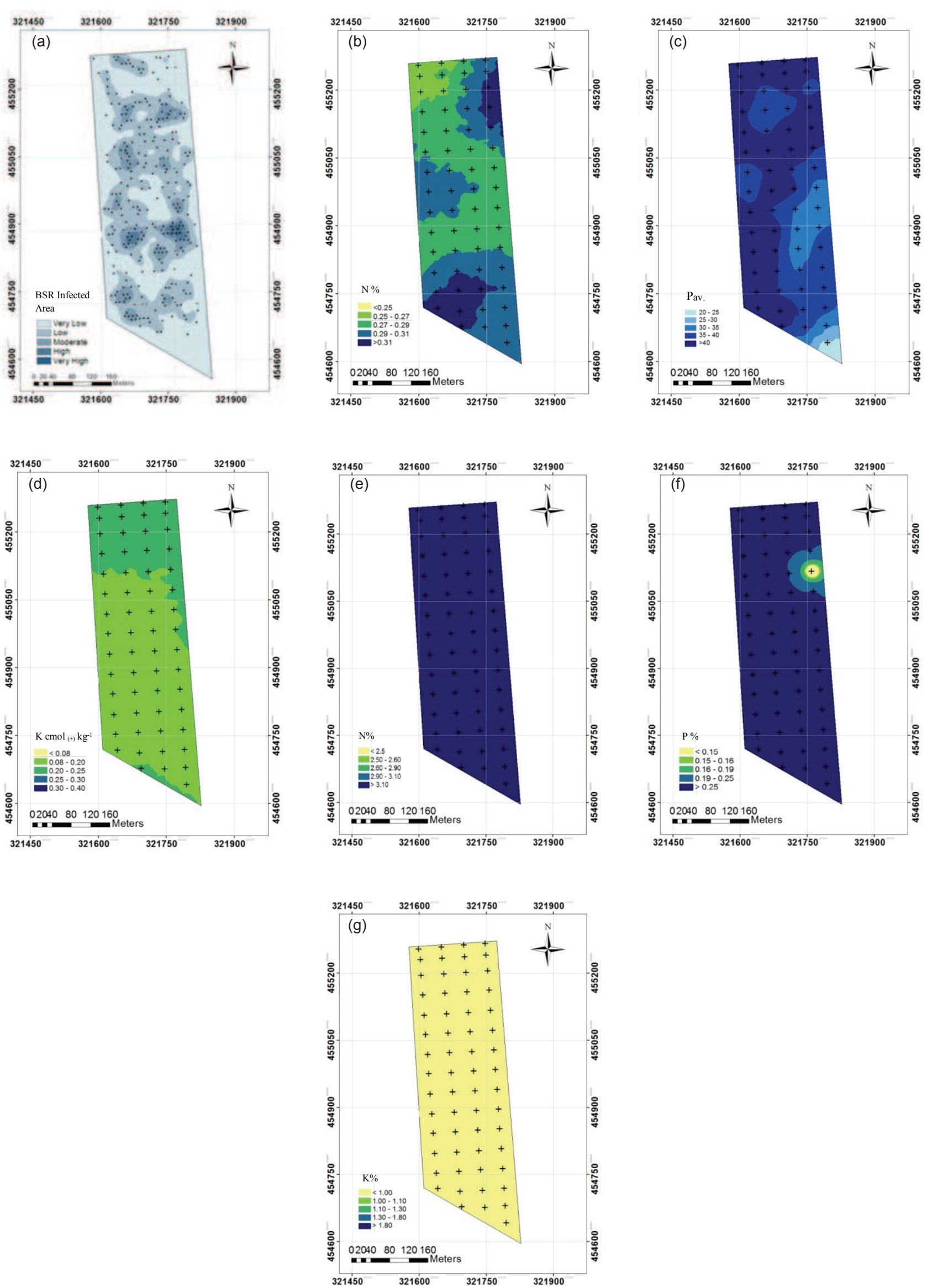

Figure 5. Distribution of basal stem rot (BSR) infected oil palm (a) and spatial variability of nitrogen (N), phosphorus (P) and potassium (K) in soil $(b-d)$ and leaf $(e-g)$ of Block 2. 
Total $\mathrm{N}$ and av. P in soil of Blocks 1 and 2 were classified as very high according to soil fertility evaluation for oil palm growth suggested as Goh and Chew (1997). The ex. K varied from low to moderate in both blocks. Age of palms does not influence the variability of total $\mathrm{N}$, av. P and ex. K in soil as the results did not show any significant different $(p<0.05)$ between the blocks. The same trend was also observed in leaf, where $\mathrm{N}$ and $\mathrm{P}$ were found higher than the optimum level in both blocks. However, low content of leaf $\mathrm{K}$ was observed in both study blocks. Based on the optimum nutrient suggested by Von Uexkull and Fairhust (1991) for oil palm, imbalance content of nutrient in soil and leaf in the study area could be observed. The mean values of the nutrient were distinct form nutrient value suggested by Goh and Chew (1997) and Von Uexkull and Fairhust (1991) for soil and leaf, respectively. Nutritional imbalance could leads to several problems including disease tribulations. Deficiency of $\mathrm{K}$ in plants is linked to plant pathogen susceptibility because of the role $\mathrm{K}$ plays in plant metabolism. Under K deficiency, the synthesis of proteins, starch and cellulose is impaired. Besides, $\mathrm{K}$ is also important in the development of cell walls, which may directly correlate to a pathogen's ability to enter plant tissues (Spann and Schumann, 2009).

Table 4 shows the correlations between total $\mathrm{N}$, av. $\mathrm{P}$ and ex. $\mathrm{K}$ in soil and N, P and $\mathrm{K}$ in leaves. Nutrient contents of soil were found to be significantly correlated with leaves $\mathrm{N}, \mathrm{P}$, and $\mathrm{K}(\mathrm{p}<0.05)$. This shows that the nutrients in soil significantly affect the leaves content of N, P, and K. Nutrients reflect the physical conditions of the plants as different nutrients play different roles in each plant cell. The effects of mineral nutrients have also been correlated with disease interaction and severity (Meena et al., 2017). Nutrients would reduce or increase disease as they affect the physiology, biochemistry, especially the integrity of the cell walls, membrane leakage and the chemical composition of the host or plant. Study done by Fabien Fonguimgo Tengoua et al. (2014) indicated that double combinations of selected nutrients could lower BSR severity index for infected bulb tissues at the nursery stage. Other studies shown that high $\mathrm{N}$ supply has been found to increase severity of infection, e.g., Puccinia graminis
(Howard et al., 1994), Erysiphe graminis (Buschbell and Hoffmann 1992), and Oidium lycopersicum (Hoffland et al., 2000). Nevertheless, high disease susceptibility can be observed in K-deficient plants which have a direct relation to metabolic functions. In $\mathrm{K}$ deficient plants, the synthesis of highmolecular-weight compounds is severely impaired and low-molecular-weight organic compounds were accumulated, indispensable for feeding pathogens and insects (Marschner, 1995; Amtmann et al., 2008; Zörb et al., 2014).

TABLE 4. CORRELATION MATRIX OF NITROGEN (N), PHOSPHORUS (P) AND POTASSIUM (K) BETWEEN SOIL AND LEAF

\begin{tabular}{ccccccccc}
\hline & \multicolumn{2}{c}{ Total N soil } & & \multicolumn{2}{c}{ Av. P soil } & & \multicolumn{2}{c}{ Ex. K soil } \\
\cline { 2 - 3 } \cline { 7 - 8 } \cline { 7 - 8 } & B1 & B2 & & B1 & B2 & & B1 & B2 \\
\hline $\mathrm{N}_{\text {leaf }}$ & $0.71^{*}$ & $0.63^{*}$ & & 0.46 & -0.12 & & -0.001 & -0.01 \\
$\mathrm{P}_{\text {leaf }}$ & 0.36 & -0.12 & & $0.39^{*}$ & $0.73^{*}$ & & 0.13 & -0.11 \\
$\mathrm{~K}_{\text {leaf }}$ & -0.13 & -0.01 & & 0.43 & -0.29 & & $0.65^{*}$ & $0.69^{*}$ \\
\hline
\end{tabular}

Note: *Significantly correlated $\mathrm{p}<0.05$.

\section{Geostatistical Analysis}

Geostatistical analysis was computed by using $\mathrm{GS}^{+}$software to determine the spatial structure of total N, av. P and ex. K in soil of Blocks 1 and 2. The features of semi-variograms and best fit model for total N, av. P and ex. K are shown in Table 5. It was computed based on active lag of $263 \mathrm{~m}$ and $321 \mathrm{~m}$ for Blocks 1 and 2, respectively. Active lag distance is $50 \%$ of the sampling area longest dimension, while lag class interval is conventionally computed as $10 \%$ of the active lag distance value. The best fit model used for total N, av. P and ex. K of soil in Blocks 1 and 2 was Gaussian (Gauss.) and Spherical (Spher.) model, respectively. The best model and semivariogram were chosen based on trial and error and by choosing high $\mathrm{R}^{2}$ and low RSS value. Low nugget value shown in Blocks 1 and 2 for all of the nutrients indicates that only small error occurred during the estimation processes. The ratio of nugget to sill variance describes the degree of spatial correlation within the experimental site. All nutrients show strong spatial dependence in both blocks but only moderate spatial dependence was found for ex. $\mathrm{K}$ in soil of Block 1.

TABLE 5. PARAMETERS OF THEORETICAL SEMI-VARIOGRAMS OF SOIL PROPERTIES IN BLOCKS 1 AND 2

\begin{tabular}{|c|c|c|c|c|c|c|c|c|c|c|c|c|}
\hline \multirow{2}{*}{ Element } & \multicolumn{2}{|c|}{ Model } & \multicolumn{2}{|c|}{ Nugget (C0) } & \multicolumn{2}{|c|}{ Sill (C1) } & \multicolumn{2}{|c|}{ Range (m) } & \multicolumn{2}{|c|}{ R2 } & \multicolumn{2}{|c|}{ Nugget: Sill } \\
\hline & B1 & B2 & B1 & B2 & B1 & B2 & B1 & B2 & B1 & B2 & B1 & B2 \\
\hline Total N & Gauss. & Spher. & 0.00015 & 0.00003 & 0.0024 & 0.011 & 50.70 & 58.00 & 0.79 & 0.03 & 8.3 & 0.27 \\
\hline Av. P & Gauss. & Spher. & 0.100 & 0.0034 & 297.40 & 0.069 & 49.00 & 51.50 & 0.83 & 0.64 & 0.03 & 4.9 \\
\hline Ex. K & Gauss. & Spher. & 0.0042 & 0.0063 & 0.0084 & 0.12 & 73.70 & 58.70 & 0.78 & 0.76 & 50 & 5.25 \\
\hline
\end{tabular}

Note: Gauss. - Gaussian.

Spher. - spherical. 


\section{Spatial Variability of N, P and K in Soil and Leaf}

The total $\mathrm{N}$, av. $\mathrm{P}$ and ex. $\mathrm{K}$ in soil of Block 1 showed very distinct spatial patterns, where higher values of total $\mathrm{N}$, av. P and ex. K were observed at the eastern part of the block (Figures $4 b$ to $4 d$ ). Blocks 1 and 2 had a very high content of total $\mathrm{N}$ and av. $\mathrm{P}$ in soil, where their distribution throughout the study area was higher than $0.25 \%$ and $25 \mathrm{ppm}$, respectively. About 97 and $94 \%$ of areas in Blocks 1 and 2 respectively were dominated with high av. P, while $100 \%$ of the study area was dominated with high total N. Similar observations were found in the content of $\mathrm{N}$ and $\mathrm{P}$ in leaves of both blocks (Figures $4 e$ to $4 g$ and $5 e$ to $5 g$ ). In Blocks 1 and 2, respectively, about $50 \%$ and $100 \%$ of the area had excess content of $\mathrm{N}$ in leaf. About $69.73 \%$ of areas in Block 1 had high content of $\mathrm{P}$ compared to the optimum range $(0.15 \%$ to $0.18 \%$ ), while almost $100 \%$ of areas in Block 2 had excess P content with value of more than $0.25 \%$.

Sources of total $\mathrm{N}$ in the soil are from parent material, fertiliser, crop residues, ammonium and nitrate salts (Brady, 1990). Crop residues, such as fronds pile has been naturally added to the soil to improves nutrients availability. Oil palm fronds has been reported to supply $14 \%$ to $24 \%$ of annual N requirement in the oil palm fields and this contributes to more source of $\mathrm{N}$ within the soil environment (Kee and Goh, 2006). Fertilisers, such as urea, ammonium nitrate and ammonium chloride, which are applied three to four times annually also cause accumulated high level of $\mathrm{N}$ in soil. Loss of $\mathrm{N}$ in oil palm plantation through leaching processes was relatively low (Foong, 1993; Schroth et al., 2000). All these sources contribute to a heterogenous content of $\mathrm{N}$ within each block within a long-term period. These combined factors would contribute to higher $\mathrm{N}$ content within the study area.

High av. P observed within this study area could be from the natural occurence of $\mathrm{P}$ and fertiliser inputs. Addition of fertiliser twice a year especially during the young stage, which requires more $\mathrm{P}$ during the growing phase, leads to its acumulation. High P content within a routinely fertilised area is common especially in a heavy clay textured and acid type soil (Fageria, 2009). Application of P fertiliser, such as the low dissolution of phosphate rock, effects the build up of accumulated av. P within the soil environment over the time ( $\mathrm{Ng}$ et al., 2011).

About 38\% and $70 \%$ of areas in soil of Blocks 1 and 2 respectively, had low contents of ex. K (Figures $4 d$ and $5 d$ ). Similar content of $\mathrm{K}$ was found in the leaf, where almost $100 \%$ of the study areas had deficient $\mathrm{K}$ (Figures $4 g$ and $5 g$ ). Low content of $\mathrm{K}$ in the soil and leaf could be caused by crop removal during harvesting, leaching losses, erosion and runoff losses, immobilisation by microorganisms and soil colloids (Fageria, 2009). Factors of soil pH also influence the fixation of ex. $\mathrm{K}$ in soils where, in strong acidic soil, the tightly held hydrogen and hydroxyl aluminium ions are able to keep the ex. $\mathrm{K}$ ions from close association with the colloidal surfaces, which reduce their susceptible to fixation. Spatial analyst technique allows us to have a visual illustration on behaviour of each element in our study areas besides it also helps in identifying areas that need a specific management approach.

\section{Correlations of N, P and K with BSR Disease Incidence}

Table 6 shows the correlation between N, P and $\mathrm{K}$ in soil and leaf with BSR disease incidence in both blocks. The correlation indicates that total $\mathrm{N}$ in soil tends to have a significant positive correlation with BSR disease in both blocks $(\mathrm{p}<0.05)$. A positive and significant correlation of BSR incidence with $\mathrm{N}$ was also observed in leaves collected from Block $1(p<0.05)$. N content was found to be high in both soil and leaf collected from the study areas. At high $\mathrm{N}$ rates, the maturity of the plant tissue delays. Higher growth rate that occurs will promote more production of young tissues (Marschner, 1995). Young tissues are susceptible to pathogens compared to the matured plants. Nevertheless at high $\mathrm{N}$, the key enzymes of phenol metabolisms have low activity and thus decrease the phenolic and lignin compounds that are required as a part of defence system against disease infection (Fageria, 2009). This disposes the oil palm to be more susceptible to disease attack through a weak defence system. Excessive $\mathrm{N}$ would also reduce the silicon (Si) content, which is also important for disease resistance by creating a physical barrier which can restrict fungal penetration (Volk et al., 1958). All this combined factors affect the disease tolerance or resistance of the plants to the pathogens. Nevertheless, the effects of $\mathrm{N}$ on crop disease varied in the literature. This could be due to the different responses depending on the pathogens and type of $\mathrm{N}$ applied to the plants. The causal pathogen and its effect is complex and more research is needed to find the specific mechanism that describes these observations since the interaction between the host and the pathogen depends on several factors including type of soil, previous crops, age of oil palms, host response, planting techniques and nutrient status (Ariffin et al., 2000).

Similar result was also found in fertiliser trials of $\mathrm{N}, \mathrm{P}$ and $\mathrm{K}$ on oil palm plantation in North Sumatra. Results obtained showed that higher $\mathrm{N}$ and $\mathrm{P}$ fertilisers had significantly increased the number of dead palms due to BSR disease. The effect of high $\mathrm{N}$ in increasing BSR disease has also been shown in a number of trials in Malaysia (Tayeb and Hamdan, 2000).

Significantly positive correlations were observed between contents of av. $\mathrm{P}$ in soil of Blocks 1 
and 2 with BSR disease. P is important for root development and its fertilisation had been improved to encourage more root growth. One of the ways for the spread of Ganoderma is through root contact with the inoculum of infected oil palm (Chung, 2011). Excessive root growth will increase possibility of roots of adjacent palms to be in contact. It increases the probability of the disease to be spread to the next oil palm via root contact. Nevertheless, the role of $\mathrm{P}$ in disease resistance is varied and inconsistent (Dordas, 2008). Experiments in Bernam series soil and MPOB Teluk Intan Research Station, Perak, Malaysia also reported that $\mathrm{P}$ fertiliser trials had significantly increased BSR disease (Singh, 1990).

TABLE 6. CORRELATION OF SOIL AND LEAF NUTRIENT WITH BASAL STEM ROT (BSR) DISEASE INCIDENCE (\%) IN BLOCKS 1 AND 2

\begin{tabular}{lccc}
\hline Soil & Total N & Av. P & Ex. K \\
\hline BSR incidence (\%) in Block 1 & $0.74^{*}$ & $0.51^{*}$ & 0.24 \\
BSR incidence (\%) in Block 2 & $0.54^{*}$ & $0.46^{*}$ & 0.21 \\
\hline Leaf & $\mathbf{N}$ & $\mathbf{P}$ & $\mathbf{K}$ \\
\hline BSR incidence (\%) in Block 1 & $0.49^{*}$ & $0.56^{*}$ & 0.32 \\
BSR incidence (\%) in Block 2 & 0.03 & 0.04 & -0.05 \\
\hline
\end{tabular}

Note: *Significantly correlated at $\mathrm{p}<0.05$.

$\mathrm{N}$ - nitrogen.

$\mathrm{P}$ - phosphorus.

$\mathrm{K}$ - potassium.

\section{CONCLUSION}

Geospatial approaches in this study demonstrated a better way in quantifying nutrient of large oil palm plantation. Distribution of BSR disease varied from very low to very high categories of infected area. Mature oil palm plantation was dominated by moderate to a very high category of BSR infected area. However, $94 \%$ of areas in young oil palm plantation were still categorised as very low to low. Soil variability map revealed $100 \%$ of the study areas had high total N, while $97 \%$ and $94 \%$ of areas in Blocks 1 and 2, respectively had high av. P. Similar to N and P in leaves of both blocks with $100 \%$ of the area had high content of $\mathrm{N}$ and $70 \%$ of areas in Block 1 had high content of $\mathrm{P}$ and $100 \%$ of areas in Block 2 had excess P content with value of more than $0.25 \%$. Total $\mathrm{N}$ and av. P in soil of both blocks, showed a strong associations with BSR disease. However, only $\mathrm{N}$ and $\mathrm{P}$ in leaf of Block 1 showed a significant associations with the disease. The content of N, P and K in soil and leaf play important role in influencing the spread of the disease as it could affect the disease resistance, tolerance of plant to the pathogen and virulence of the pathogen itself. Lower association of nutrient with BSR disease in young oil palm suggests that age of oil palm could be one of the factors that influence disease resistance, and this needs further investigation. Nutrients were observed to be imbalanced and can be improved through the use of site specific management practices. These combined data suggest the need of site specific approach in managing nutrients in oil palm plantation areas in order to reduce BSR disease occurrence at the early stage of planting and thus conserve time and money.

\section{REFERENCES}

Agrios, G (2005). Plant Pathology. $5^{\text {th }}$ Edition. Elsevier Academic Press, Amsterdam, The Netherlands. 952 pp.

Amber, A B; Wade, F B and Laurence, D C (2005). Using GIS in area wide pest management: A case study in South Dakota. Trans. GIS, 9: 109127.

Amtmann, A; Troufflard, S and Armengaud, P (2008). The effect of potassium nutrition on pest and disease resistance in plants. Physiology Plant, 133: 682-691.

Ariffin, D; Idris, A S and Singh, G (2000). Status of Ganoderma in oil palm. Ganoderma Diseases of Perennial Crops (Flood, J; Bridge, P D and Holderness, $M$ eds.). Wallingford, United Kingdom: $C A B$ International. p. 49-68.

Brady, N C (1990). The Nature and Properties of Soils. Macmillan Publishing, New York, USA. 621 pp.

Bray, R H and Kurtz, L T (1945). Determination of total, organic and available forms of phosphorous in soils. Soil Science, 59: 39-45.

Bremner, J M and Mulvaney, C S (1982). Nitrogen total. Methods of soil analysis. Agronomy Monograph (Miller, R H and Keeney, D R eds.). American Society of Agronomy, Madison. p. 295-324.

Burgess, T M and Webster, R (1980). Optimal interpolation and isarithmic mapping of soil properties. J. Soil Science, 31: 315-331.

Buschbell, T and Hoffmann, G M (1992). The effects of different nitrogen regimes on the epidemiologic development of pathogens on winter-wheat and their control. J. Plant Diseases and Protection, 99: 381403.

Cambardella, C A; Moorrman, T B; Novak, J M; Parkin, T B; Karalan, D L; Turco, R F and Konopka, A E (1994). Field scale variability of soil properties in central Iowa soils. Soil Science Society of America, 58: 1501-1511. 
Chung, G F (2011). Management of Ganoderma diseases in oil palm plantations. The Planter, $87: 325-$ 339.

Dordas, C (2008). The role of nutrients in controlling plant diseases in sustainable agriculture. Agronomy for Sustainable Development, 28: 33-46.

Dorsel, D (1997). Environmental sampling and monitoring primer kringing. http;/ / www.ce.vt. edu/program_areas / environmental / teach / suprimer/ kriging/krging.html\#TheoryEgns, accessed on 20 April 2012.

Fageria, N K (2009). The Use of Nutrients in Crop Plants. CRC Press, Boca Raton, York, USA. 448 pp.

Fabien, F T; Hanafi, M M; Idris, A; Jugah, K; Mayziatul, N A J; Hasmah, M and Syed Omar, S R (2011). Effect of micronutrients-enriched fertilizers on basal stem rot disease incidence and severity on oil palm (Elaeis guineensis Jacq.) seedlings. Amer. J. Applied Sciences, 11: 1841-1859.

Foong, S F (1993). Potential evapotranspiration, potential yield and leaching losses of oil palm. Proc. of the PORIM International Palm Oil Congress. PORIM, Bangi. p. 105-119.

Graham, R D and Webb, M J (1991). Micronutrients and disease resistance and tolerance in plants. Micronutrients in Agriculture (Mortvedt, J J; Cox, F R; Schuman, L M and Welch, R M eds.). Soil Science Society of America, Madison, USA. p. 329-370.

Goh, K J and Chew, P S (1997). Interpretations of analytical data from soil survey reports for manuring recommendations: Some pointers. Annual Journal/Report. Royal Johor Planters' Association, Johor. p. 25-30.

Goh, K J and Chew, P S (1995). Managing soils for plantation tree crops I: General soil management. Course on Soil Survey and Managing Tropical Soils (Paramanathan, S ed.). p. 228-245.

Havlin, J L; Beaton, J D; Tisdale, S L and Nelson, W L (1999). Soil Fertility and Fertilizers. $6^{\text {th }}$ Edition. Prentice Hall, New Jersey, USA. 499 pp.

Hoffland, E; Jeger, M G and Van Beusichem, M L (2000). Effect of nitrogen supply rate on disease resistance in tomato depends on the pathogen. Plant Soil, 218: 239-247.

Howard, D D; Chambers, A Y and Logan, J (1994). Nitrogen and fungicide effects on yields components and disease severity in wheat. J. Production Agriculture, 7: 448-454.
Huber, D M (1980). The role of mineral nutrition in defence. Plant Pathology: An Advance Treaties (Horsfall, J G and Cowling, E B eds.). Academic Press, New York, USA. p. 381-406.

Huber, D M and Graham, R D (1999). The role of nutrition in crop resistance and tolerance to diseases. Mineral Nutrition of Crops: Fundamental Mechanisms and Implications (Rengel, Z ed.). Food Products Press, New York, USA. 169 pp.

Isaaks, E H and Srivastava, R M (1989). An Introduction to Applied Geostatistic. Oxford University Press, New York, USA. 561 pp.

Kee, K K and Goh, K J (2006). Efficient fertilizer management for higher productivity and sustainability in oil palm production. International Planters Conference on Higher Productivity and Efficient Practices for Sustainable Plantation. Agriculture Vol. 1: Technical Papers. p. 157-182.

Lindgren, C J (2012). Biosecurity policy and the use of geospatial predictive tools to address invasive plants: Updating the risk analysis toolbox. Risk Analysis, 32: 9-15.

Marschner, H (1995). Mineral Nutrition of Higher Plants. Academic, London. p. 889.

Meena, V S; Maurya, B R; Meena, S K; Meena, R K; Kumar, A; Verma, J P and Singh, N P (2017). Can Bacillus species enhance nutrient availability in agricultural soils? Bacilli and Agrobiotechnology (Islam, M T; Rahman, M; Pandey, P; Jha, C K and Aeron, A eds.). Springer International Publishing. p. 367-395.

Nelson, M R; Orum, T V; Jaime-Garcia, R and Nadeem, A (1999). Applications of Geographic Information Systems and geostatistics in plant disease epidemiology and management. Plant Disease, 83: 308-319.

Ng, H C P; Gan, H H and Goh, K J (2011). Soil nutrient changes in ultisols under oil palm in Johor, Malaysia. J. Oil Palm and the Environment, 2: 93-104.

Pimentel-Gomes, F and Garcia, C H (2002). Statistics applied to agronomic and forestry experiments. Exposure to Examples and Guidelines for Use by Applications (Pimentel-Gomes, F ed.). Piracicaba, Fealq-Esalq. 309 pp.

Schroth, G; Rodrigues, M R L and Angelo, S A D (2000). Spatial patterns of nitrogen mineralization, fertilizer distribution and roots explain nitrate leaching from mature Amazonian oil palm plantation. Soil Use and Management, 16: 222-229. 
Scholleneberger, C J and Simon, R H (1945). Determination of exchangeable capacity and exchangeable bases in soil-ammonium acetate method. Soil Science Research, 14: 61-168.

Singh, G (1990). Ganoderma - The scourge of oil palms in the coastal areas. Proc. of the Ganoderma Workshop. PORIM, Bangi. p. 7-35.

Spann, T M and Schumann, A W (2009). The role of plant nutrients in disease development with emphasis on citrus and huanglongbing. Proc. Fla. State Hort. Soc., 122: 169171.

Tayeb, D M and Hamdan, A B (2000). Relationship of fertilizer nutrients to Ganoderma. Proc. of the PORIM International Oil Palm Congress. PORIM, Bangi. p. 422-453.

Tayeb, M D; Idris, A S and Haniff, M H (2003). Reduction of Ganoderma infection in oil palm through balanced fertilization in peat. Proc. of the 2003 PIPOC International Palm Oil
Congress - Agriculture Conference. MPOB, Bangi. p. 139-219.

USDA (2012). Malaysia: Stagnating palm oil yields impede growth. Commodity Intelligence Report (December 2012). 4 pp. http:/ / www.pecad.fas.usda. gov/ highlights / 2012/12 / Malaysia/

Volk, J R; Kahn, R P and Weintraub, R L (1958). Silicon content of rice plants as a factor influencing the resistance to infection by the blast fungus Piricularia oryzae. Phytopathology, 48: 179-184.

Von Uexkull, H R and Fairhurst, T H (1991). Fertilizing for high yield and quality. The Oil Palm. International Potash Institute, Switzerland. 79 pp.

Webster, R and Oliver, M A (1992). Sample adequately to estimate variogram of soil properties. J. Soil Science, 43: 177-192.

Zorb, C; Senbayram, M and Peiter, E (2014). Potassium in agriculture - Status and perspectives. J. Plant Physiology, 171: 656-669. 